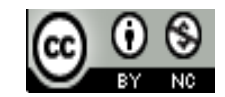

Journal of Education, Teaching, and Learning is licensed under

A Creative Commons Attribution-NonCommercial 4.0 International License.

\title{
THE SURVEY OF 2013 CURRICULUM IMPLEMENTATION ON PHYSICAL EDUCATION IN THE ELEMENTARY SCHOOLS OF BEKASI CITY
}

\author{
Yusmawati $^{1)}$, Aridhotul Haqiyah ${ }^{2)}$, Dani Nur Riyadi ${ }^{3)}$ \\ ${ }^{1)}$ Universitas Negeri Jakarta, Jakarta, Indonesia \\ E-mail: yusmawati@unj.ac.id \\ ${ }^{2)}$ Universitas Islam 45, Bekasi, Indonesia \\ E-mail: aridhotulhaqiyah@unismabekasi.ac.id \\ ${ }^{3)}$ Universitas Negeri Jakarta, Jakarta, Indonesia \\ E-mail: daninurriyadigundarya@yahoo.com
}

\begin{abstract}
The purpose of this study was to find out the implementation of the 2013 Curriculum in Bekasi Elementary Schools. The method used in this study is the survey method. The sample in this study was a physical education teacher who taught at the Bekasi Elementary School amount of 30 people. The instrument used by the questionnaire of teaching indicators which include: (a) preparation factors, (b) application factors, and (c) evaluation factors. Data analysis technique were descriptive statistics by using the SPSS Version 23 program. The result showed that the 2013 curriculum implementation of physical education teachers is viewed from 3 factors which are as follows: (1) Preparation shows the very high result as many as $32.6 \%$, while as many as $14.8 \%$ answered very low, $7.3 \%$ answered low, $16.3 \%$ answered moderate, and $29.1 \%$ answered high, (2) Application shows the high result as many as $35.1 \%$, while as many as $16.4 \%$ answered very low, $14.1 \%$ answered low, $12.6 \%$ answered moderate, and $21.9 \%$ answered very high, (3) Evaluation shows the high result as many as $41.9 \%$, while $7.6 \%$ answered very low, $7.6 \%$ answered low, $11 \%$ answered moderate, and $31.9 \%$ answered very high. So, the implementation of the 2013 curriculum in Physical Education subjects in Bekasi is already good in the preparation factor and needs improvement in application and the evaluation.
\end{abstract}

Keywords: 2013 Curriculum; Elementary Schools; Physical Education

\section{INTRODUCTION}

The main task of a teacher in realizing the goals of education in schools is to develop effective teaching and learning strategies. The development of this strategy is intended as an effort to create conditions that can affect the lives of students so that they can enjoy learning and achieve satisfying learning achievements. Therefore, carrying out teaching and learning activities is complex work and requires the seriousness of the teacher.

In connection with the implementation of the task above, the teacher certainly requires adequate knowledge regarding the Developmentally Appropriate Practice (DAP) (Jenkins, Hewitt, \& Wade, 2012), which is an approach to teaching and learning strategies oriented to the development of children or students. A teacher who is good at teaching is not enough to only be equipped with explaining or asking skills, rather they should also master other teaching skills. Therefore, this paper aims to provide fun teaching and learning activities for students so that they can achieve brilliant achievements.

The implementation of the physical education program should reflect the characteristics of the physical education program itself, namely "Developmentally Appropriate Practice" (DAP). This means that teaching tasks submitted should pay attention to changes in children's abilities or conditions and can help drive these changes. Thus, the teaching tasks should be following the level of development and the level of maturity of the students they teach. The development or maturity referred to includes physical, psychological and skills.

In the early academic year of 2013-2014, the Ministry of Education and Culture arranged a new curriculum in 2013. The curriculum would be done in classification (step by step) 
for basic education (elementary and secondary school) and also middle education (Anwar, 2014). The policy of the 2013 curriculum change is based on internal and external challenges that are faced by some Indonesian people to prepare for their future generation that is much more productive, creative, innovative and effective.

Teachers' understanding and acceptance of the 2013 curriculum will be different from each other. Elementary physical education teachers who have a long term of service will have difficulty adjusting to the demands of the 2013 curriculum. This is because elementary physical education teachers who have long tenure are already familiar with the previous curriculum. While in the 2013 curriculum, elementary physical education teachers are required to develop creativity in preparing material and conduct teaching and learning process following the conditions of their students. Teachers who are used to learning methods that have been applied for a long time will find it difficult to make more varied methods. Therefore, it requires elementary physical education teachers to be able to develop creativity in learning which is fun and following the conditions of students, as well as the conditions and potential of the region, because there are supporting factors and inhibiting factors, alternative solutions, and the role of principals and teachers in the implementation of Curriculum 2013 (Ningrum \& Sobri, 2015).

The process of studying and elaborating on an object is also influenced by the status of the elementary physical education teacher. Teachers with permanent status generally have broad autonomy to develop their creativity and in the implementation and preparation of learning materials. Meanwhile, non-permanent teachers do not have the autonomy to develop creativity as broad as that of permanent teachers. Likewise, the class of teacher positions, the higher the class of a teacher, shows that the teacher has a relatively long work period, an achiever in his field, has high education and is experienced in participating in the training. Teachers with high-class positions will therefore tend to be easier to study and elaborate the 2013 curriculum.

In PP No 32 the year 2013, it was found that four of eight national educational standards has significantly changed. The four standards are: (1) the graduation competency standard has been revised and renewed in Permendikbud No 54 the year 2013; (2) the content standard is renewed in Permendikbud No 64 the year 2013; (3) the process standard is renewed in Permendikbud No 65 the year 2013; and (4) evaluation standard is renewed in Permendikbud No 66 the year 2013. One of the four standards that are very interesting to discuss is the process standard which is focusing on how the ideal model of a teacher plans, implements, and evaluates the teaching and learning process. This process standard is one of the curriculum anatomies which covers a model, approach, strategy, method, and technique of teaching implemented by a teacher in administering the content of learning to achieve the goals of teaching has been made (Shafa, 2014).

Therefore, to find out how the implementation of the 2013 curriculum for elementary physical education teachers in
Bekasi City, it is necessary to conduct a study regarding the implementation of the 2013 curriculum by physical education teachers of elementary schools in Bekasi City.

\section{Methodology}

This research is classified as descriptive research which is only limited to the attempt to express a problem and the situation as it is so that it is merely revealing facts. The method used in this study is a survey method through the distribution of questionnaires containing the stages of teaching conducted by the teachers in the implementation of physical education learning processes in the field. This research was conducted in January 2019 and located at the 45th Islamic University of Bekasi, Jl. Cut Meutia No. 83 Bekasi. 30 physical education teachers teach at elementary schools in Bekasi City. The instrument used in this study was the 2013 Curriculum Implementation Questionnaire in Elementary Schools consisting of the indicators: (a) Preparation factor, (b) Application factor, (c) Evaluation factors. The grids can be seen in Table I.

TABLE I

RESEARCH INSTRUMENT GRID

\begin{tabular}{|c|c|c|c|c|}
\hline Variable & Factor & Indicator & Question Item & $\begin{array}{l}\text { Total } \\
\text { Item }\end{array}$ \\
\hline \multirow{4}{*}{$\begin{array}{l}\text { The Survey of } \\
2013 \text { Curriculum } \\
\text { Implementation } \\
\text { in the Elementary } \\
\text { Schools of Bekasi } \\
\text { City }\end{array}$} & Preparation & $\begin{array}{l}\text { 1. Written } \\
\text { 2. Planning }\end{array}$ & $\begin{array}{l}1,2,3,4,5,6, \\
7,8^{*}, 9^{*}, 10^{*}, \\
11^{*}, 12,13, \\
14^{*}, 15^{*}\end{array}$ & 15 \\
\hline & Application & $\begin{array}{l}\text { 1. Lesson opening } \\
\text { 2. Material } \\
\text { 3. Teaching and } \\
\text { learning method } \\
\text { 4. Lesson closing }\end{array}$ & $\begin{array}{l}16,17,18,19, \\
20,21^{*}, 22^{*}, \\
23^{*}, 24^{*}, 25, \\
26,27^{*}, 28^{*}, \\
29,30,31,32, \\
33,34^{*}, 35^{*}, \\
36^{*}, 37^{*}, 38^{*}\end{array}$ & 23 \\
\hline & Evaluation & $\begin{array}{l}\text { 1. Spiritual } \\
\text { 2. Social } \\
\text { 3. Cognitive } \\
\text { 4. Psychomotor }\end{array}$ & $\begin{array}{l}39,40,41,42, \\
43,44^{*}, 45^{*}\end{array}$ & 7 \\
\hline & & & Total & 45 \\
\hline
\end{tabular}

The measurement of teacher implementation variables for the 2013 curriculum is based on the indicators. The measurement scale used is a Likert scale, which is a scale used to measure attitudes, opinions or groups of people about social phenomena. The validity test of the instrument used was the correlation between the question items with the total sub-variables with the total overall score using Pearson's correlation formula. The results can be seen in Table II (Kadir, 2015). Data analysis of preparation factor, implementation factor, evaluation factor, and total implementation of physical education teachers towards the 2013 curriculum through descriptive statistics which were processed by using the SPSS Version 23 program.

TABLE II

RELIABILITY STATISTICS

\begin{tabular}{cc}
\hline Cronbach's Alpha & N of Items \\
\hline .972 & 45 \\
\hline
\end{tabular}




\section{RESULTS AND DISCUSSION}

Description of respondents (Muhamad \& Aridhotul, 2015) by gender can be seen in Table III.

TABLE III

GENDER OF RESPONDENT

\begin{tabular}{rlrrrr}
\hline & Frequency & Percent & $\begin{array}{c}\text { Valid } \\
\text { Percent }\end{array}$ & $\begin{array}{c}\text { Cumulative } \\
\text { Percent }\end{array}$ \\
\hline Valid & Male & 25 & 83.3 & 83.3 & 83.3 \\
& Female & 5 & 16.7 & 16.7 & 100 \\
& Total & 30 & 100 & 100 & \\
\hline
\end{tabular}

Table III shows that 25 people $(83.3 \%)$ of respondents are male and 5 people $(16.7 \%)$ of respondents are female. Description of respondents based on years of service can be seen in Table IV.

TABLE IV

WORK EXPERIENCE OF RESPONDENT

\begin{tabular}{|c|c|c|c|c|c|}
\hline & & Frequency & Percent & $\begin{array}{c}\text { Valid } \\
\text { Percent }\end{array}$ & $\begin{array}{c}\text { Cumulative } \\
\text { Percent }\end{array}$ \\
\hline \multirow[t]{3}{*}{ Valid } & $<5$ Years & 27 & 90 & 90 & 90 \\
\hline & $>5$ Years & 3 & 10 & 10 & 100 \\
\hline & Total & 30 & 100 & 100 & \\
\hline
\end{tabular}

Table IV shows that 27 people (90\%) of respondents have a service period of $<5$ years and 3 people $(10 \%)$ of respondents have a service period of $>5$ years.

\section{A. Results}

Based on the results of data analysis of preparation factor, implementation factor, evaluation factor, and total implementation of physical education teachers towards the 2013 curriculum, which were processed by using the SPSS Version 23 program, the results of descriptive statistics can be seen in Table $\mathrm{V}$.

TABLE V

DESCRIPTIVE STATISTICS

\begin{tabular}{lrrrrr} 
& N & Minimum & Maximum & Mean & $\begin{array}{c}\text { Std. } \\
\text { Deviation }\end{array}$ \\
\hline Preparation & 30 & 28 & 71 & 53,43 & 7,496 \\
Application & 30 & 58 & 96 & 76,37 & 11,421 \\
Evaluation & 30 & 20 & 35 & 26,80 & 4,715 \\
Valid N (listwise) & 30 & & & & \\
\hline
\end{tabular}

\section{1) Preparation for the 2013 Curriculum Implementation}

Based on the data of physical education teacher preparation factor for the 2013 curriculum, which were processed by using the SPSS 23 program, descriptive statistical results were obtained, in which the preparation factor scores from 28 to 71 with an average value of 53.43 and a standard deviation of 7.469 can be seen in Fig. 1 .

Of the 30 respondents, the distribution of respondents' answers was obtained for the 2013 curriculum preparation factor, in which as many as $14.8 \%$ answered very low, $7.3 \%$ answered low, $16.3 \%$ answered moderate, $29.1 \%$ answered high, and $32.6 \%$ answered very high. It shows that of the 30 respondents, it is dominated by the respondents who answered very high at $32.6 \%$.

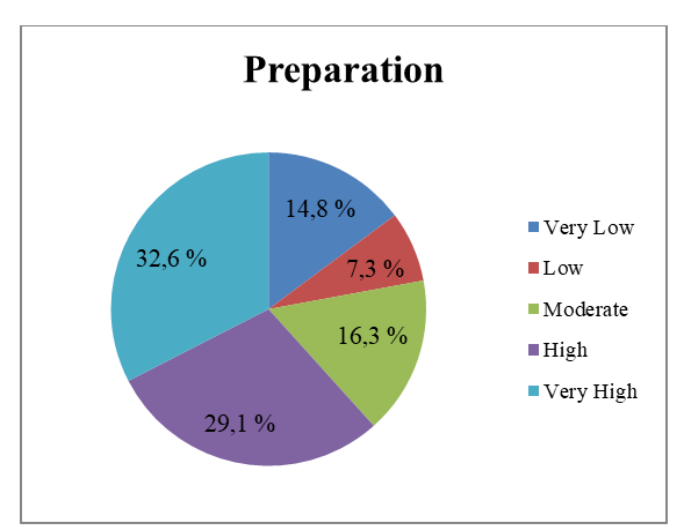

Fig. 1 Diagram of Preparation Factor for the 2013 Curriculum Implementation

\section{2) Application of the 2013 Curriculum Implementation}

Based on the data of physical education teacher application factor for the 2013 curriculum, which were processed by using the SPSS 23 program, descriptive statistical results were obtained, in which the application factor scores from 58 to 96 with an average value of 53.43 and a standard deviation of 11.421 .

Of the 30 respondents, the distribution of respondents' answers was obtained for the 2013 curriculum application factor, in which as many as $16.4 \%$ answered very low, $14.1 \%$ answered low, $12.6 \%$ answered moderate, $35.1 \%$ answered high, and $21.9 \%$ answered very high. It shows that of the 30 respondents, it is dominated by the respondents who answered high at $35.1 \%$. Further details can be seen in Fig. 2 .

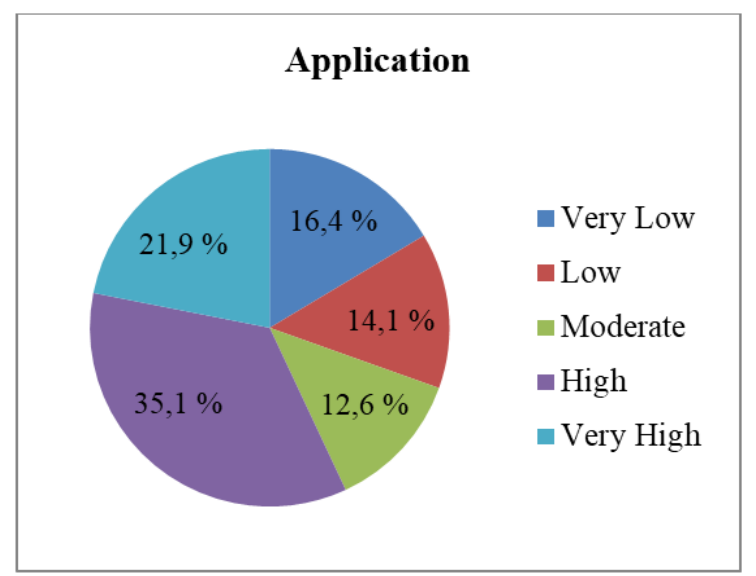

Fig. 2 Diagram of Application Factor for the 2013 Curriculum Implementation

\section{3) Evaluation of the 2013 Curriculum Implementation}

Based on the data of physical education teacher evaluation factor for the 2013 curriculum, which were processed by using the SPSS 23 program, descriptive statistical results were obtained in which the evaluation factor scores from 20 to 35 with an average of 26.80 and a standard deviation of 4.715 . 
Of the 30 respondents, the distribution of respondents' answers was obtained for the 2013 curriculum evaluation factor, in which as many as $7.6 \%$ answered very low, $7.6 \%$ answered low, $11 \%$ answered moderate, $41.9 \%$ answered high, and $31.9 \%$ answered very high. It shows that of the 30 respondents, it is dominated by the respondents who answered high at $41.9 \%$. Further details can be seen in Fig. 3.

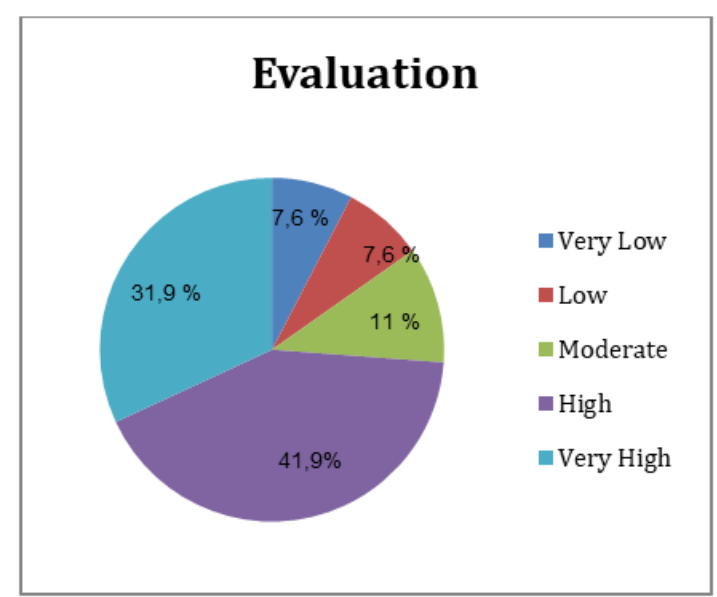

Fig. 3 Diagram of Evaluation Factor for 2013 Curriculum Implementation

\section{4) Recapitulation of Physical Education Teacher Implementation on 2013 Curriculum}

Of the 30 respondents, the distribution of answers for the total physical education teachers implementation on the 2013 curriculum showed $14.5 \%$ of them answered very low, $10.8 \%$ answered low, $13.6 \%$ answered moderate, $34.1 \%$ answered high, and $27 \%$ answered very high. It shows that of the 30 respondents, it is dominated by the respondents who answered high at $34.1 \%$. Further details can be seen in Fig. 4.

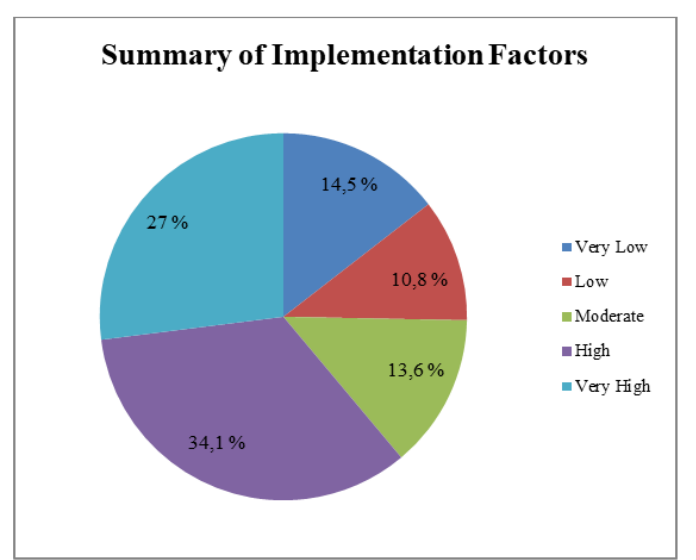

Fig. 4 Recapitulation Diagram of 2013 Curriculum Implementation Factors

\section{B. Discussion}

Successful implementation of the curriculum requires good management. To implement the 2013 curriculum, there are several important aspects of management as a strategy to strengthen its implementation. These aspects include implementation planning, main and supporting resources, learning processes in schools, and monitoring and evaluation activities (Katuuk, 2014). Implementation of Curriculum 2013 in schools independent organizer can run well by the support of compliance with education national standards and teachers who have the motivation, creativity, and good performance, and focuses more on all subjects must support all competencies both in attitudes, skills, and knowledge (Budiani \& Syamwil, 2017; Qomariyah, 2014).

This study seeks to uncover three factors to find out how the efforts of physical education teachers in implementing the 2013 Curriculum. The three factors are to prepare, apply, and evaluate the 2013 curriculum. The results of the study indicate that school teachers' response to the implementation of the 2013 curriculum falls into the category of "positive" (Rusman, 2015). Although the positive effect of physical activity on the cognitive, social, and physical development of young children is generally acknowledged, there is little emphasis nationally on ensuring appropriate physical educational experiences within the curriculum (Stork \& Sanders, 2008).

The physical education teacher preparation factor in the implementation of the 2013 curriculum consists of 15 statements containing written preparations and preparation of teaching and learning process design based on the 2013 curriculum. Application factor carried out by physical education teachers consist of 23 statement items containing opening the lessons, teaching materials, learning methods, and closing the lessons according to the 2013 curriculum. The evaluation factors carried out by the teacher were 7 statements that contain spiritual, social, cognitive and psychomotor activities. The total number of statements were 45 statement items added by filling in the respondent's identity, such as gender, the status of physical education teacher and length of service. The answer score for each statement is a Likert scale: 1 to 5 .

Based on the analysis technique as stated in the data processing results above, the implementation of physical education teachers for the 2013 curriculum can be discussed as follows:

\section{1) Implementation of Physical Education Teachers for 2013 Curriculum Preparation}

An activity/program will not run well if there is no careful preparation of the intended activity/program. Likewise, this applies to the implementation of the 2013 curriculum. To uncover the preparation of physical education teachers in implementing the 2013 curriculum, the researcher submitted items of subjective statements to the physical education teachers concerning the preparation in implementing the 2013 curriculum according to the National Education Law.

In the physical education teacher preparation factor in the implementation of the 2013 curriculum through three indicators summarized from the National Education Law, there are two preparations namely written preparation and planning preparation. For the results of the data tabulation obtained in the field, it can be seen that from 30 respondents, the distribution of respondents' answers to the 2013 
curriculum preparation factor was obtained, in which as many as $14.8 \%$ answered very low, $7.3 \%$ answered low, $16.3 \%$ answered moderate, $29.1 \%$ answered high, and $32.6 \%$ answered very high. It appears that of the 30 respondents, it is dominated by respondents who answered very high at $32.6 \%$.

The preparation factor in the implementation of the 2013 curriculum is intended to equalize the implementation of all parties involved in the preparation of the 2013 curriculum implementation in the field of elementary physical education, particularly regarding written preparation and planning preparation which form the basis and basic conception of development, provide signs which can direct all parties involved in the implementation of the elementary physical education curriculum, become a reference in monitoring and evaluating the implementation of the elementary physical education curriculum as a material for further guidance.

This preparation factor, namely the implementation of the 2013 curriculum concept regarding preparation can be considered to be high, even though not all of the teachers implemented it well. This shows that the implementation of physical education teachers in preparation for the implementation of the 2013 curriculum is well understood by most of the physical education teachers in the state elementary schools in Bekasi City. This means that to implement the 2013 curriculum concept as a whole, most of the teachers already know the foundation of creating the program which is being the goal, as well as the curriculum development. In this case, the teacher knows the basis for implementing the curriculum. The 2013 curriculum as a new curriculum in education contains very complex things in it and demands creativity and innovation from physical education teachers, especially in terms of curriculum development. Data on the implementation was obtained from a questionnaire about the concept as had been mentioned earlier.

\section{2) Implementation of Physical Education Teachers for the 2013 Curriculum Application}

This factor discusses the application and assessment of student physical education learning outcomes. Application of the progress assessment and student learning outcomes learning is directed to measure and assess student performance (aspects of knowledge, skills, and attitudes), both directly when students carry out physical education activities or indirectly, namely through evidence of learning outcomes following performance criteria organized in the form of lesson opening, teaching materials, learning methods, and lesson closing. Besides, there is a need for an assurance system and quality control which involve relevant parties.

In the physical education teacher application factor in the implementation of the 2013 curriculum, it can be seen that from the 30 respondents, the distribution of respondents' answers to the 2013 curriculum application factor was obtained, in which as many as $16.4 \%$ answered very low, $14.1 \%$ answered low, $12.6 \%$ answered moderate, $35.1 \%$ answered high, and $21.9 \%$ answered very high. It appears that of the 30 respondents, it is dominated by the respondents who answered high at $35.1 \%$.

The available data show that the application of physical education teachers on the implementation of the 2013 curriculum which is all about application, starting from the lesson opening, teaching material, learning method, to lesson closing, is quite understood by most of the physical education teachers in state elementary schools in Bekasi City. This means that generally, the teachers apply the implementation of lesson opening, teaching material, learning method, lesson closing, both directly when students carry out learning activities or indirectly, namely through evidence of learning outcomes.

\section{3) Implementation of Physical Education Teachers on Curriculum 2013 Evaluation}

The curriculum evaluation procedures discussed in the evaluation factor of the physical education teacher implementation of the 2013 curriculum contain spiritual, social, cognitive and psychomotor activities. The results of this factor data, namely the 2013 curriculum evaluation, can be seen that of the 30 respondents, the distribution of respondents' answers for the 2013 curriculum evaluation factor was obtained, in which as many as $7.6 \%$ answered very low, $7.6 \%$ answered low, $11 \%$ answered moderate, $41.9 \%$ answered high, and $31.9 \%$ answered very high. It shows that of the 30 respondents, it is dominated by the respondents who answered high at $41.9 \%$. This shows that the physical education teacher implementation on the 2013 curriculum evaluation of spiritual, social, cognitive and psychomotor activities in the 2013 curriculum implementation is quite understood by most of the physical education teachers in the state elementary schools in Bekasi City. This means that the majority of teachers implement the 2013 curriculum evaluation containing standard operating evaluation procedures in terms of implementing the 2013 curriculum, namely adjusting the Learning Guidelines Outline, compiling learning programs, compiling modules, managing learning, evaluating activities and learning outcomes. The teacher's implementation of this evaluation factor will greatly influence the physical education teacher's follow-up in implementing the 2013 curriculum.

\section{4) Implementation of Physical Education Teachers towards the 2013 Curriculum}

The teacher is one of the spearheads in supporting the implementation of the 2013 curriculum. The success of a program is inseparable from the implementation done by the physical education teacher associated with the program application. Therefore, in this study, the efforts of physical education teachers are emphasized on the preparation, application, and evaluation factors.

From the above data, the implementation of physical education teachers to the 2013 curriculum in the state elementary schools in Bekasi City, it can be seen that from the 30 respondents, the distribution of answers was obtained for the total implementation of physical education teachers towards the 2013 curriculum, namely $14.5 \%$ answered very 
low, $10.8 \%$ answered low, $13.6 \%$ answered moderate, $34.1 \%$ answered high, and $27 \%$ answered very high. It shows that of the 30 respondents, it is dominated by the respondents who answered high at $34.1 \%$.

\section{CONCLUSIONS}

The conclusion in the discussion of this paper is that the 2013 curriculum implementation of physical education teachers is viewed from 3 factors which are as follows: (1) Preparation shows the very high result as many as $32.6 \%$, while as many as $14.8 \%$ answered very low, $7.3 \%$ answered low, $16.3 \%$ answered moderate, and $29.1 \%$ answered high, (2) Application shows the high result as many as $35.1 \%$, while as many as $16.4 \%$ answered very low, $14.1 \%$ answered low, $12.6 \%$ answered moderate, and $21.9 \%$ answered very high, (3) Evaluation shows the high result as many as $41.9 \%$, while $7.6 \%$ answered very low, $7.6 \%$ answered low, $11 \%$ answered moderate, and $31.9 \%$ answered very high. So, the implementation of the 2013 curriculum in Physical Education subjects in Bekasi is already good in the preparation factor and needs improvement in application and the evaluation.

\section{REFERENCES}

Anwar, R. (2014). Hal-Hal yang Mendasari Penerapan Kurikulum 2013. Humaniora. https://doi.org/10.21512/humaniora.v5i1.2987

Budiani, S., \& Syamwil, R. (2017). Evaluasi Implementasi Kurikulum 2013 di Sekolah Pelaksana Mandiri Abstrak, 6(53), 45-57.

Jenkins, K. L., Hewitt, A., \& Wade, C. (2012). Defining Developmentally Appropriate Practices (DAP) For Preservice Teachers Through Modeling In Higher Education Classrooms. In EDULEARN12: 4th International Conference On Education And New Learning Technologies.

Kadir. (2015). Statistika Terapan. Jakarta: PT. Rajagrafindo Persada.

Katuuk, D. A. (2014). Manajemen Implementasi Kurikulum: Strategi Penguatan Implementasi Kurikulum 2013. Jurnal Cakrawala Pendidikan. https://doi.org/10.21831/cp.v1i1.1858

Muhamad, Memet., Aridhotul, H. (2015). Diktat statistik olahraga. FKIP: UNISMA Bekasi.

Ningrum, E. S., \& Sobri, A. Y. (2015). Implementasi Kurikulum 2013 Di Sekolah Dasar. Manajemen Pendidikan.

Qomariyah. (2014). Kesiapan Guru dalam Menghadapi Implementasi Kurikulum 2013. Jurnal Pendidikan Ekonomi IKIP Veteran Semarang.

Rusman. (2015). Curriculum Implementation at Elementary Schools: A Study on "Best Practices" Done by Elementary School Teachers in Planning, Implementing, and Evaluating the Curriculum. Journal of Education and Practice.

Shafa. (2014). Karakteristik Proses Pembelajaran Kurikulum 2013. Jurnal Dinamika Ilmu.
https://doi.org/10.1061/(ASCE)07339410(1991) 117

Stork, S., \& Sanders, S. W. (2008). Physical education in early childhood. Elementary School Journal. https://doi.org/10.1086/529102 